\title{
Enjoy Some Southern Hospitality
}

APSA is heading south for this year's Annual Meeting. Led by program co-chairs John Garcia, University of Arizona, and Alberta Sbragia, University of Pittsburgh, the 1999 meeting will feature over 700 panels beginning on September 2 and lasting through mid-day September 5. A day of professional development workshops and sessions will be held on September 1. For more informatioin on events and sessions, visit the Annual Meeting web site (www. apsanet.org/99AM).

The $95^{\text {th }}$ Meeting will be cohosted by the Atlanta Marriott Marquis and the Atlanta Hilton and Towers, located in the heart of downtown Atlanta. The headquarters and overflow hotels are all within walking distance of the Peachtree Center MARTA (i.e., subway) station. Atlanta has developed into an entertainment and cultural center, due largely to its vast number of restaurants, professional sporting events, entertainment venues, and cultural attractions.

From art and music to gardens and zoos, Atlanta is a great city to explore. To get a real feel for the city, wander through Ansley Park, Virginia-Highland, Little Fivẹ Points, Buckhead, and Centennial Park. Other places to visit include the Atlanta Botanical Gardens, the CNN Center, the Fernbank Museum of Natural History, the historic Fox Theatre, the High Museum of Art, the Margaret Mitchell House, the Carter Center, the Martin Luther King, Jr. Center, Underground Atlanta, World of Coca-Cola Atlanta, and Zoo Atlanta. Stop along the way to enjoy a variety of southern cuisines and local delicacies and for a view of the streetscapes.

It's never too early to start exploring Atlanta. For a more detailed look at the city and its surroundings visit the following web sites:

\section{Insiders' Guide to Atlanta www.insiders.com/atlanta \\ Yahoo! Atlanta dir.yahoo.com/Regional/ U_S_States/Georgia/ Metropolitan_Areas/ Atlanta_Metro \\ Fun Stuff in Atlanta www.oglethorpe.edu/atlanta}

\section{Parts of Town}

It's easy to navigate various parts of Atlanta-check out these web sites for specific information on areas of the city.

\author{
Buckhead \\ www.buckhead.org \\ Little Five Points \\ www.patweb.com $/ 15 p$ \\ Underground Atlanta \\ www.underatl.com \\ Midtown Atlanta \\ www.midtownatlanta.org
}

\section{Family}

Atlanta is a great place to bring your family. Visit the following web sites for planning family entertainment.
Atlanta Braves www.atlantabraves.com
Zoo Atlanta www.zooatlanta.org
Centennial Olympic Park www.gwcc.com/parkinfo.htm
The World of Coca-Cola www.webguide.com/coke.html

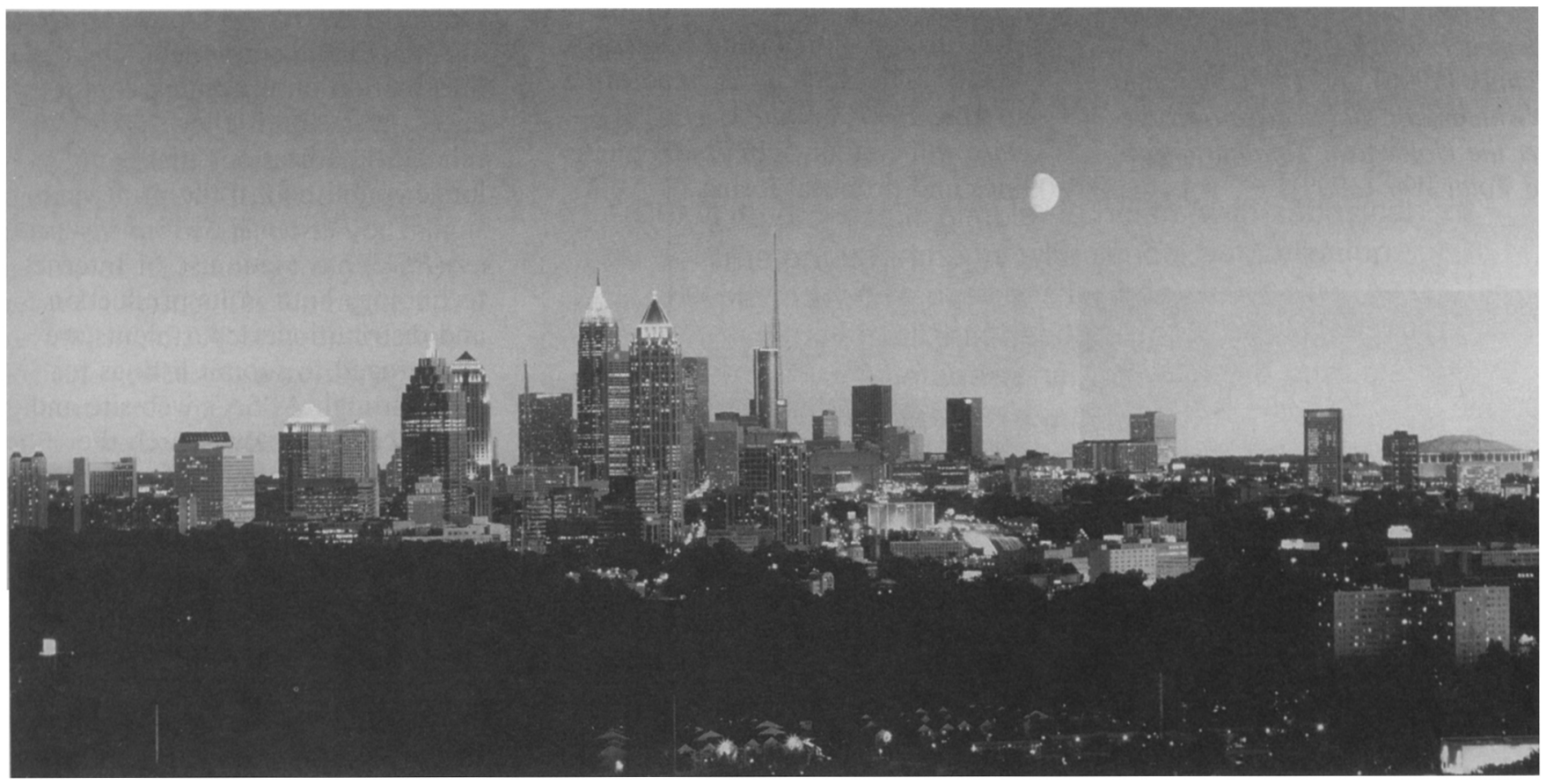

Heart of the South: The Atlanta skyline featuring the stair-shaped Georgia Pacific building, the CNN Tower, and the Georgia Dome. Photo courtesy of the Atlanta Convention and Visitors Bureau. 
SciTrek - The Science \& Technology

Museum www.scitrek.org

Atlanta Botanical Gardens www.atlantabotanicalgarden.org

Six Flags Over Georgia www.sixflags.com/atlanta

Foam Factory www.whitewaterpark.com/other

\section{History \& the Arts}

So, you've walked through the neighborhoods, shopped, and grabbed something to eat. It's time to visit some of the many educational sites.

Margaret Mitchell House www.gwtw.org

\section{Milner and Katznelson Named Program Co-Chairs for APSA 2000}

APSA is pleased to announce that Helen Milner and Ira Katznelson have been named Program Committee Co-Chairs for the 2000 Annual Meeting in Washington, DC, August 31-September 3.

Helen Milner joined the political science faculty at Columbia University in 1986 . Her most recent books are The Political Economy of Economic Regionalism (1997, coedited with Edward Mansfield) and Interests, Institutions and Information: Domestic Politics and International Relations (1997).

Ira Katznelson joined the faculty at Columbia University as Ruggles Professor of Political Science and History in 1994. He has taught at the University of Chicago and the New School for Social Research. His most recent books are Liberalism's Crooked Circle: Letters to Adam Michnik (1996) and Desolation and Enlightenment: Political Knowledge after the Holocaust, Totalitarianism, and Total War (1999).

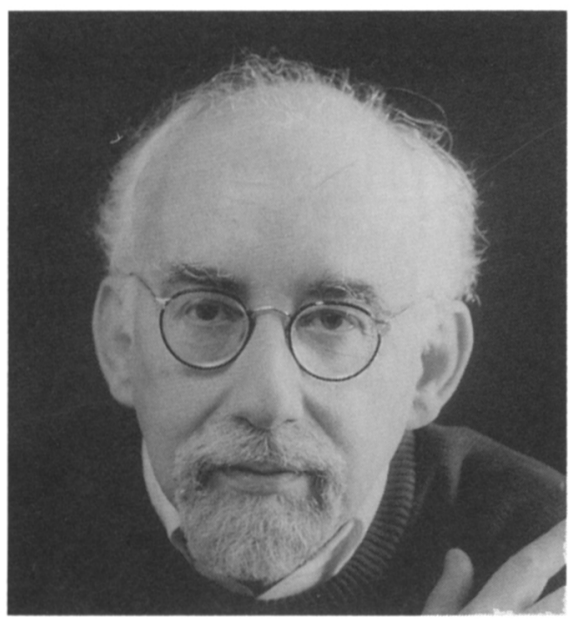

Ira Katznelson
The theme for the $96^{\text {th }}$ Annual Meeting is "Political Science as Discipline? Reconsidering Power, Choice, and the State at Century's End." Power, choice, and the state have been central concepts in political science since its founding as a self-conscious discipline. By reconsidering these orienting themes, the program chairs seek to initiate discussion about both the distinguishing characteristics and internal coherence of political science as well as late-century developments that challenge how the discipline deploys its key organizing concepts.

APSA will begin accepting proposals in September 1999 for panels, papers, and posters related to the organizing theme as well as proposals addressing topics covering the 43 divisions, or subfields, of political science. The September issue of $P S$ and the 1999 Annual Meeting Program will contain submission guidelines and proposal forms.

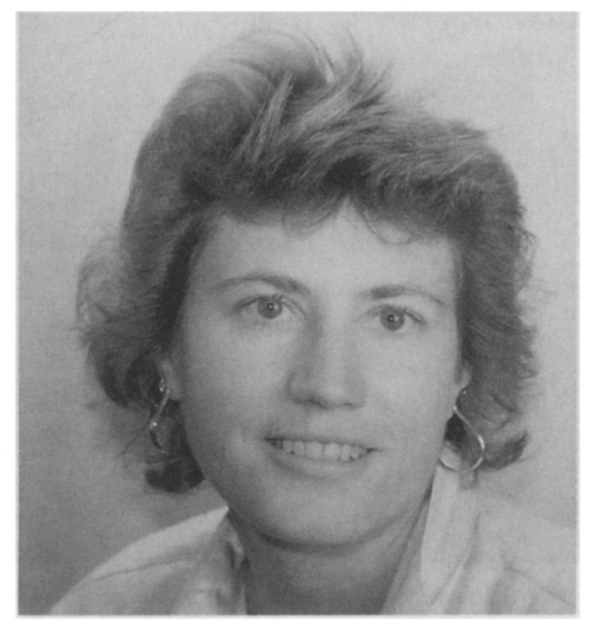

Helen Milner
Fernbank Museum of Natural History www.fernbank.edu

Martin Luther King, Jr. National

Historic Site www.nps.gov/malu

The Carter Center www.CarterCenter.org

High Museum of Art www.high.org

Fox Theatre www.thefoxtheatre.com

\section{Transportation}

Need flight or public transportation information? Visit these web sites. www.itsmarta.com www.atlanta-airport.com

\section{APSA Expands Online Services}

APSA is developing new online resources as it expands its current offerings. APSA's web site (www. apsanet.org) serves as the primary locus of these efforts. In the past year, the Association launched PSonline, PSN Online and the Civic Education Network (CENnet), and the Association plans to introduce a scholar exchange service in early 1999 .

PSonline includes many of the items featured in the print version of PS: Political Science and Politics, including "Washington Insider," scholarly essays and topical articles, and also offers continually updated information on upcoming conferences, grants and fellowships, and related organizations that is no longer published in the print version. The Personnel Service Newsletter (PSN) has made use of Internet technology both in its production and distribution: departments are encouraged to submit listings for PSN through APSA's web site and subscribers can now search the newsletter in its online format.

The Civic Education Network (CENnet) is a resource for civic education teachers at all levels. The site (www.apsanet.org/CENnet) includes scholarly essays and links to civic education resources and organizations. A collection of syllabi and lesson plans and a section on online classrooms are in development. The Association encourages its members 